\title{
PERBANDINGAN NILAI EKONOMI LAHAN DALAM KASUS KONVERSI LAHAN SAWAH DI KECAMATAN PRAYA KABUPATEN LOMBOK TENGAH
}

\author{
Ahmad Syalabi Mujahid1), Agam Marsoyo2) \\ 1,2Departemen Teknik Arsitektur dan Perencanaan, Magister Perencanaan Wilayah dan Kota, \\ Universitas Gadjah Mada \\ 1ahmadsyalabi@mail.ugm.ac.id, 2agam@ugm.ac.id
}

\begin{abstract}
Abstrak: Lahan sawah di Kabupaten Lombok Tengah terus berkurang dengan laju 0,05\% per tahun. Penyusutan tertinggi terdapat di Kecamatan Praya sebagai kecamatan dalam kawasan Perkotaan Praya. Penelitian ini bertujuan membandingkan nilai lahan sawah yang belum terkonversi dan dan telah terkonversi di Kecamatan Praya, Kabupaten Lombok Tengah. Melalui teknik analisis data spasial diidentifikasi petak sawah baik yang belum ataupun sudah terkonversi untuk kemudian dijadikan unit analisis. Nilai ekonomi lahan dihitung dengan pendekatan land rent. Hasil penelitian menunjukkan terdapat 13 bentuk konversi sawah dengan rasio nilai lahan sawah terhadap non sawah sebesar 1 : 32,7 menunjukkan besarnya nilai opportunity cost yang dapat diduga menjadi alasan pemilik lahan tidak mempertahankan lahan sawahnya.
\end{abstract}

Kata kunci: konversi sawah, land rent, nilai lahan, opportunity cost

\begin{abstract}
Paddy fields in Central Lombok Regency remain to subside at a rate of $0.05 \%$ per year. The highest depreciation was found in Praya Subdistrict as a sub-district included in the Praya Urban Area. This study aims to determine the comparison of land values after the conversion of paddy fields in Praya District. Through spatial data analysis, rice fields could be identified either converted or those that remain exsist. In this research, the land economic value calculated using the land rent approach. The results showed that there were 13 forms of paddyfield/rice field conversion with a ratio between paddy to non-paddy by $1: 32,7$. This ratio shows the value of opportunity cost that can be questionable as a reason for landlord to discharge their paddy fields.
\end{abstract}

Keywords: land rent, land value, opportunity cost, paddy fields conversion

\section{PENDAHULUAN}

Data Kementerian Pertanian (2018) menunjukkan adanya laju penyusutan mencapai 0,05\% pertahun dalam penurunan luas sawah di Kabupaten Lombok Tengah dari tahun 2011 sampai tahun 2017. Penyusutan ini menunjukkan adanya perubahan preferensi masyarakat dalam memanfaatkan lahan mereka dari sektor pertanian ke non pertanian. Keadaan ini dapat menjadi indikator keterancaman daerah Lombok Tengah dalam upaya mewujudkan ketahanan pangan, mengingat laju pertumbuhan penduduk di Kabupaten Lombok Tengah pada tahun 2011-2017 menurut BPS (2019) telah mencapai $0,91 \%$ pertahun. Bertambahnya jumlah penduduk seharusnya membutuhkan produksi pangan yang bertambah yang berarti membutuhkan penambahan areal penanaman bahan pangan tersebut secara spasial.

Dalam RTRW Kabupaten Lombok Tengah 2011-2031, penguatan urbanisasi diarahkan dengan penetapan kawasan Perkotaan Praya yang mencakup 25 desa dan kelurahan di Kecamatan Praya, Praya Tengah, Jonggat, Praya Barat, Praya Barat Daya dan Pujut dengan luas 15.832,5 Ha. Dorongan urbanisasi yang tumbuh dari fungsi perkotaan tersebut, sebagaimana diteorikan oleh Krannich, (2006); Harini, et.al, (2012); Nguyen, et.al, (2016); serta Solecka, et.al, (2017) patut diduga sebagai pemicu tingginya konversi lahan pertanian di Kabupaten Lombok Tengah. Hal ini dapat diamati dari data BPS 
sepanjang tahun 2006-2018 yang mencatat penyusutan luas sawah terbesar terjadi di Kecamatan Praya sebagai lokasi ibukota Kabupaten Lombok Tengah yang berfungsi sebagai Pusat Kegiatan Wilayah (PKW) dalam struktur Tata Ruang Wilayah Nasional. Laju penyusutan luas sawah di Kecamatan Praya sebesar $0,39 \%$ per tahun yang berarti lebih tinggi dari laju penyusutan luas sawah di Kabupaten Lombok Tengah sendiri

Dengan logika ketahanan pangan dan upaya perlindungan lahan sawah, beberapa kalangan kemudian menganggap konversi lahan sawah ini sebagai hal yang harus dicegah. Namun di sisi lain, pembangunan wilayah sebagaimana yang diupayakan pemerintah daerah dan seluruh masyarakat mensyaratkan terjadinya pertumbuhan ekonomi melalui peningkatan pendapatan masyarakat yang dapat dihasilkan melalui proses akumulasi investasi terhadap modal produksi yang dimiliki masyarakat (Harvey dalam Jauhiainen, 2006). Terpinggirkannya lahan sawah sebagai preferensi masyarakat dalam penggunaan lahan ini harus dianalisis lebih jauh lagi untuk menghasilkan temuan yang dapat membantu dalam memahami fenomena konversi sawah di Kecamatan Praya, Kabupaten Lombok Tengah secara obyektif dan rasional.

Dalam kajian keruangan, konversi lahan sawah dipandang sebagai hal yang lumrah terjadi sebagai konsekuensi logis atas terjadinya pergeseran nilai lahan. Dalam pandangan ini, lahan dipandang sebagai modal produksi yang dapat dimanfaatkan secara efektif dalam memperoleh profit secara ekonomi. Secara ekonomis, perubahan lahan adalah hal logis yang diputuskan pemilik lahan sebagai aktor rasional. Menurut Rustiadi, et. al. (2009), alih fungsi lahan merupakan konsekuensi logis atas dinamika pergeseran land rent dari jenis aktivitas yang rendah ke yang tinggi. Dalam kasus konversi lahan sawah, perubahan tersebut dengan demikian seharusnya dapat dimaknai secara positif sebagai proses pencarian titik keseimbangan spasial yang lebih produktif. Untuk memastikan efektifitas dari penggunaan lahan yang direncanakan, beberapa pendekatan dapat dijadikan pegangan sebagai alat pembenaran dan pijakan berfikir rasional diantaranya melalui pendekatan nilai lahan.

Penelitian terkait konversi lahan sawah sudah banyak ditemukan dengan berbagai pendekatan dan fokus penelitian yang berbeda-beda termasuk berdasarkan pendekatan nilai lahan seperti yang dilakukan dalam penelitian ini. Akib (2002), Pambudi (2008), Hamdan (2012), dan Rondhi, et. al. (2018) misalnya telah mencoba memberikan penjelasan terkait teori land rent dalam menggambarkan fenomena konversi sawah di beberapa lokasi penelitian hanya saja temuan yang dihasilkan masih terbatas pada konversi lahan sawah menjadi beberapa jenis peruntukan lahan saja. Akib (2002) membatasi diri pada perubahan sawah menjadi lahan pertanian buah dan sayuran di Kecamatan Pancoran Mas Kota Depok. Pambudi (2008) meneliti nilai lahan dalam konversi sawah di Kecamatan Ciampea Kabupaten Bogor dengan membatasi penelitiannya pada bentuk konversi sawah menjadi permukiman sebagaimana juga dilakukan oleh Rondhi, et.l (2018) di Kabupaten Jember, Jawa Timur. Hamdan (2012) membatasi penelitiannya mengkaji nilai lahan sawah dalam kasus konversi sawah menjadi kebun kelapa sawit di Kecamatan Seluma Selatan Kabupaten Seluma. Penelitian ini berbeda dengan penelitian yang sudah ada karena penelitian ini membandingkan nilai lahan sawah dengan berbagai bentuk penggunaan lahan lainnya yang dijumpai di Kecamatan Praya pada tahun 2010-2018.

Berdasarkan latar belakang yang telah dideskripsikan di atas, penulisan penelitian ini menitiberatkan pada kajian mengenai nilai ekonomi lahan pada areal sawah yang telah mengalami konversi di Kecamatan Praya. Tujuan penelitian ini adalah untuk membandingkan nilai lahan antara sawah yang sudah terkonversi dan yang belum terkonversi di Kecamatan Praya Kabupaten Lombok Tengah. Penelitian ini diharapkan bermanfaat sebagai bahan pertimbangan dalam perencanaan pembangunan wilayah dan kota di lokasi penelitian.

\section{METODE PENELITIAN}

Penelitian ini merupakan penelitian deskriptif kuantitatif dengan unit analisis petak sawah sepanjang jalan utama di Kecamatan Praya dari tahun 2010-2018, baik yang masih bertahan menjadi sawah maupun yang telah terkonversi menjadi bentuk penggunaan lahan lainnya. Dalam penelitian ini 
dilakukan analisis data spasial untuk mengetahui sebaran konversi lahan sawah yang terjadi di Kecamatan Praya tahun 2010 hingga 2018 menggunakan Citra Quickbird tahun 2010 dan Citra Google Earth tahun 2018. Hasil analisis tersebut menghasilkan peta sebaran konversi sawah yang terjadi di sepanjang jalan utama di Kecamatan Praya.

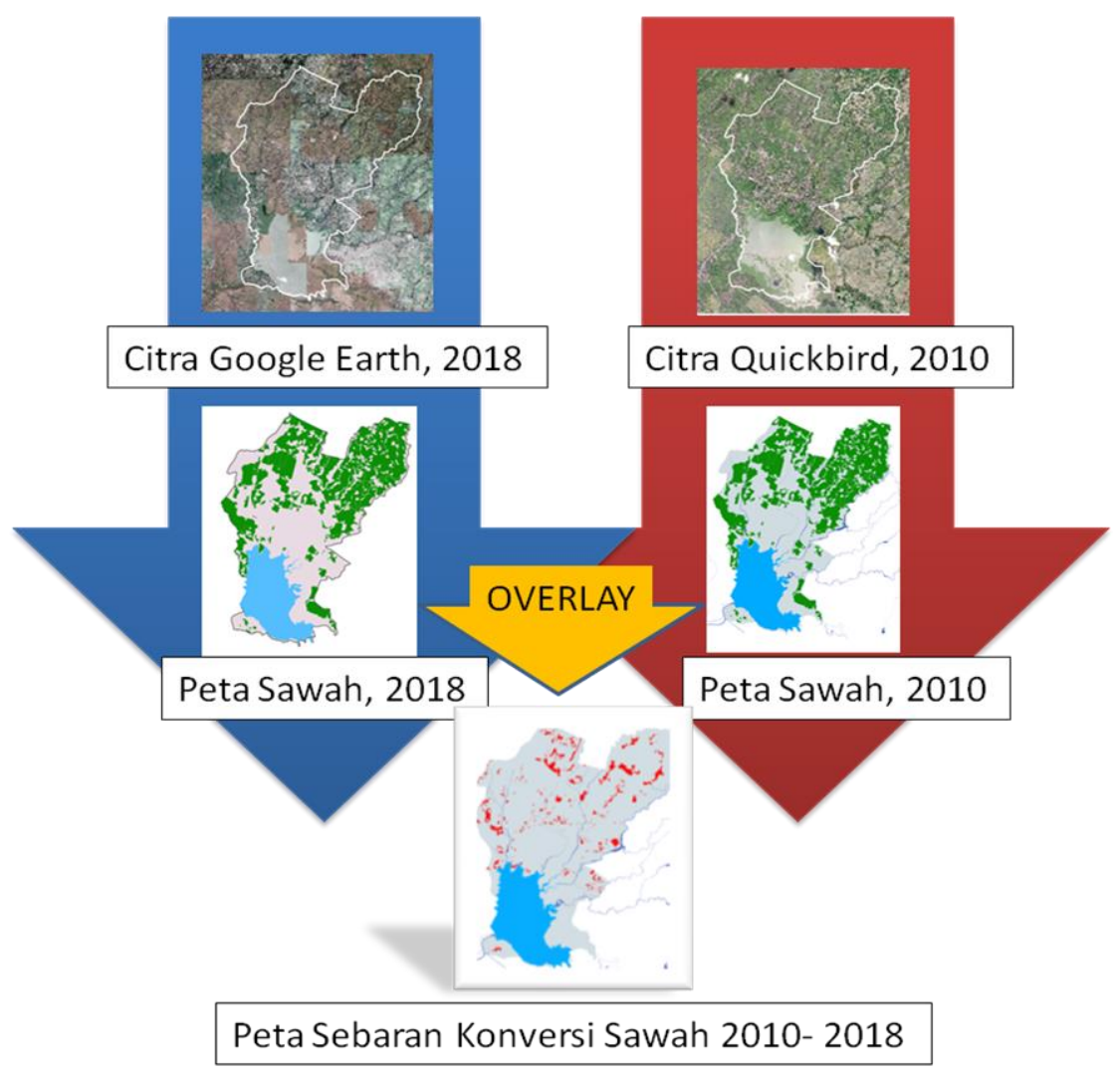

Gambar 1. Analisis Data Spasial dalam Penelitian

(Sumber : Penulis, 2019)

Jumlah dan sebaran data hasil analisis spasial tersebut kemudian dijadikan populasi dalam penelitian ini. Dengan menggunakan rumus Slovin ditentukan jumlah sampelnya.

$$
n=\frac{N}{N d^{2}+1}
$$

\section{Dimana:}

$\mathrm{n}=$ Jumlah sampel

$\mathrm{N}=$ Jumlah populasi

$d=$ Tingkat kepercayaan $(95 \%)$

Untuk populasi lahan sawah yang tidak terkonversi sebanyak 3.238 petak sawah didapatkan jumlah sampel dengan tingkat kepercayaan 95\% sebanyak 357 unit dan dari 1.394 unit populasi lahan yang terkonversi diperoleh sampel sebanyak 311 unit. Penentuan sampel untuk sawah yang tidak terkonversi menggunakan teknis simple random sampling sedangkan sampel untuk sawah yang terkonversi diambil dengan metode proportionate stratified random sampling setelah dilakukan observasi/ grand tour di lapangan. 


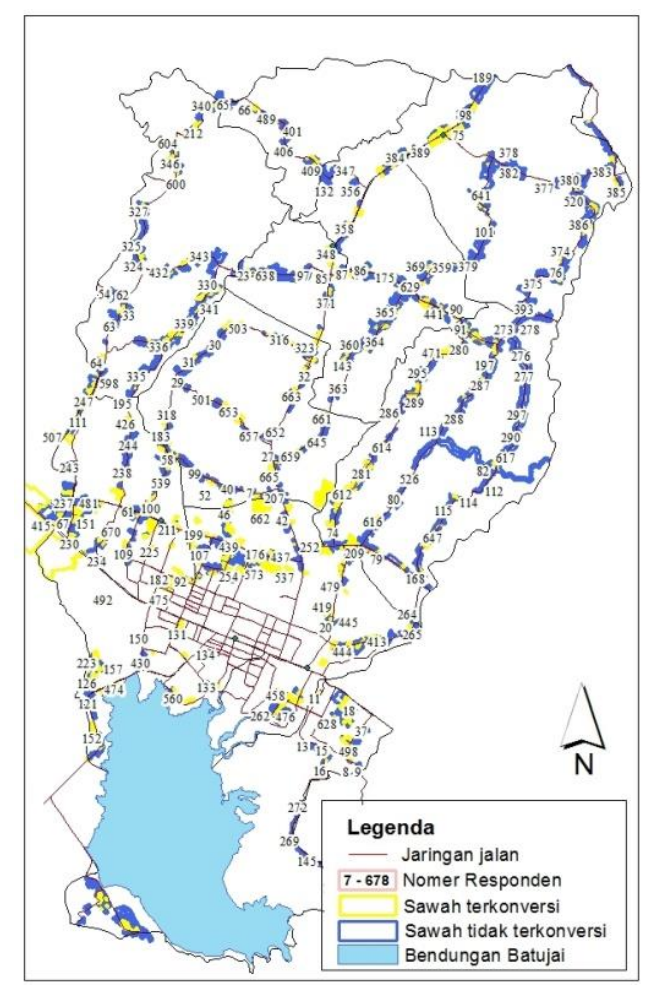

Gambar 2. Peta Sebaran Sampel Penelitian (Sumber : Penulis, 2019)

Tabel1. Jenis Perubahan Lahan Konversi Sawah Kecamatan Praya Tahun 2010-2018

\begin{tabular}{clccc}
\hline No. & \multicolumn{1}{c}{ Nama } & Jumlah petak & Persentase (\%) & Sampel \\
\hline 1 & Rumah & 852 & 61.12 & 216 \\
2 & Ruko & 117 & 8.39 & 34 \\
3 & Bengkel & 11 & 0.79 & 3 \\
4 & Apotek & 2 & 0.14 & 1 \\
5 & Heuleur & 3 & 0.22 & 2 \\
6 & Gudang & 5 & 0.36 & 1 \\
7 & Klinik & 2 & 0.14 & 1 \\
8 & Lapangan Futsal & 2 & 0.14 & 4 \\
9 & Usaha Rombeng & 1 & 0.07 & 1 \\
10 & Pabrik Batako & 6 & 0.43 & 3 \\
11 & Toko Bangunan & 5 & 0,36 & 12 \\
12 & Warung & 382 & 27,4 & 27 \\
13 & Kandang Ayam & 6 & 0,43 & 6 \\
& Jumlah & 1.394 & 100 & 311 \\
\hline
\end{tabular}

Sumber : Survey data primer peneliti, 2019.

Setiap sampel dalam penelitian ini kemudian dihitung nilai ekonomi lahannya dengan pendekatan Land rent. Suparmoko (1997) menyebut land rent sebagai nilai surplus secara ekonomi yaitu kelebihan nilai produksi total atas nilai biaya total. Rustiadi, et. al (2009) menyebut nilai ekonomi lahan dapat dibedakan menjadi nilai intrinsik yang terkait dengan keunggulan produktivitas lahan (Ricardian rent) dan nilai yang lebih disebabkan oleh perbedaan lokasional sesuai asumsi Von Thunen (locational rent). Penelitian ini berupaya memadukan konsep dua hal tersebut melalui analisis biaya produksi di tiap jenis 
penggunan lahan yang mempertimbangkan pengeluaran untuk biaya transportasi. Rumusan yang digunakan untuk analisis land rent di tiap jenis penggunan lahan dapat ditulis sebagai berikut :

1) Land rent Sawah

$$
L R=\frac{\left(P_{x H}\right)-\Sigma C_{\mathrm{i}}}{s}
$$

Dengan :

$$
C_{i}=B_{i}+A_{i}+P_{i}+O b_{i}+T r_{i}+O_{i}+S_{i}+T n_{i}+P u_{i}+P y_{i}+P a n_{i}
$$

Dimana :

$$
\begin{array}{ll}
\mathrm{LR} & =\text { Land rent (Rp/m2/tahun) } \\
\mathrm{P} & =\text { Harga jual padi dalam GKP (Rp/kwintal) } \\
\mathrm{S} & =\text { Luas lahan (m2) } \\
\mathrm{H} & =\text { Produksi Gabah dalam satu tahun (kwintal) } \\
\mathrm{C}_{\mathrm{i}} & =\text { Seluruh biaya } 1 \text { tahun (Rp/tahun) } \\
\mathrm{A}_{\mathrm{i}} & =\text { Biaya Pengairan (Rp/tahun) } \\
\mathrm{P}_{i} & =\text { Biaya Pemupukan(Rp/tahun) } \\
\mathrm{Ob}_{i} & =\text { Biaya Pengendalian Hama(Rp/tahun) } \\
\mathrm{Tr}_{\mathrm{i}} & =\text { Biaya Pengangkutan (Rp/tahun) } \\
\mathrm{O}_{i} & =\text { Biaya Pengolahan (Rp/tahun) } \\
\mathrm{S}_{\mathrm{i}} & =\text { Biaya Persemaian (Rp/tahun) } \\
\mathrm{Tn}_{\mathrm{i}} & =\text { Biaya Penanaman (Rp/tahun) } \\
\mathrm{Pu}_{i} & =\text { Biaya Pemupukan (Rp/tahun) } \\
\mathrm{Pny}_{\mathrm{i}} & =\text { Biaya Penyiangan (Rp/tahun) } \\
\mathrm{Pan}_{i} & =\text { Biaya Panen (Rp/tahun) }
\end{array}
$$

2) Land rent Rumah/ Permukiman

$$
L R=\frac{[R t-(P l t+P j t)]}{L h}
$$

Dimana :
$\mathrm{LR}=$ Land rent (Rp/m2/tahun)
Rt = Biaya sewa (Rp/tahun)
Lh = Luas lahan (m2)
PIt = Biaya Pemeliharaan (Rp/tahun)
Pjt = Biaya Pajak (Rp/tahun)

3) Land rent Usaha Lainnya

$$
\begin{aligned}
L R & =\frac{T R-\sum T C}{L h} \\
L R & =\frac{T R-[T F C-T V C]}{L h} \ldots \\
L R & =\frac{T R-\left[\left(D_{t}\right)-\left(P l_{t}+M_{t}+E_{t}+W_{t}+S p_{t}+L_{t}+P j_{t}\right)\right]}{L h} \\
L R & =\frac{T R-\left[\left(\frac{F-g}{N}\right)-\left(P l_{t}+M_{t}+E_{t}+W_{t}+S p_{t}+L_{t}+P j_{t}\right)\right]}{L h}
\end{aligned}
$$


Dimana :

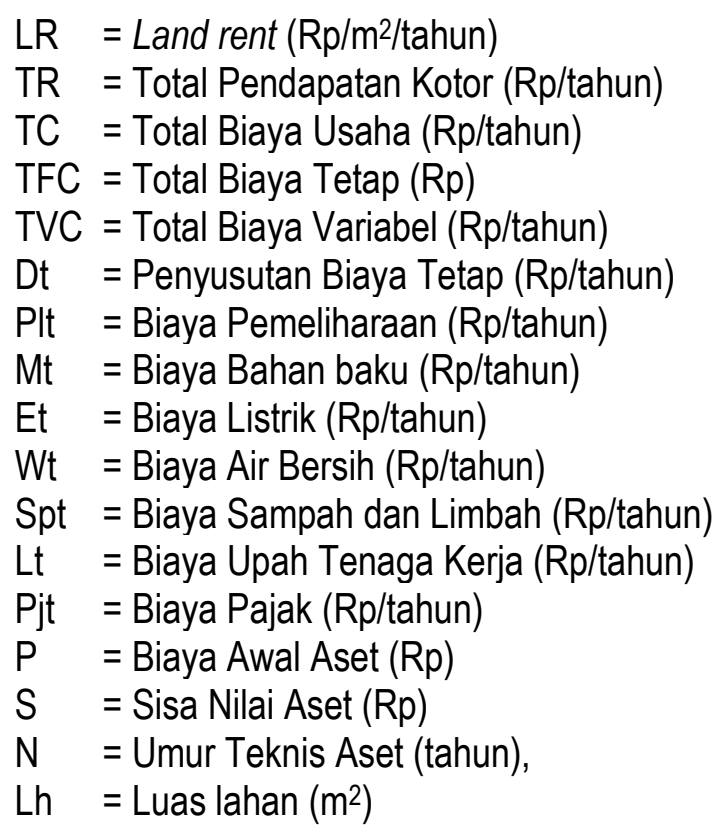

Data dalam penelitian ini diperoleh dengan menyebarkan kuesioner untuk analisis usaha produksi usaha padi sawah dan 13 jenis usaha lainnya sesuai sampel yang telah ditentukan. Data kemudian diolah menggunakan sofware Microsoft Excel 2007 untuk kemudian diintegrasikan dengan sofware ArcGis 10.1 guna analisis kualitatif dan spasial lebih lanjut. Analisis data spasial menggunakan polyghon thiessen untuk menghasilkan pola proximity distance nilai lahan sawah yang belum ataupun sudah terkonversi berdasar sebaran sampel. Agrawal \& Gupta (2016) menyebut metode ini sudah populer digunakan untuk beberapa analisis meteorologi dan analisis pasar.

\section{TEMUAN DAN PEMBAHASAN}

\section{Nilai Lahan Sawah yang Belum Terkonversi}

Berdasarkan analisis nilai lahan terhadap 14 jenis penggunaan lahan dalam penelitian ini, diketahui bahwa nilai land rent sawah rata-rata di Kecamatan Praya adalah sebesar Rp 5.317/m2/tahun. Nilai tertinggi adalah Rp. 14.877/m2/tahun dan terendah adalah minus Rp $5.120 / \mathrm{m} 2 /$ tahun. Hal ini menunjukkan dalam setahun di tiap satu meter persegi sawah di Kecamatan Praya, pemilik lahan dapat menghasilkan pendapatan bersih berkisar antara -Rp 5.120 hingga Rp 14.87 atas usaha produksi padi yang dilakukannya. Secara rata-rata, pendapatan yang dapat diperoleh

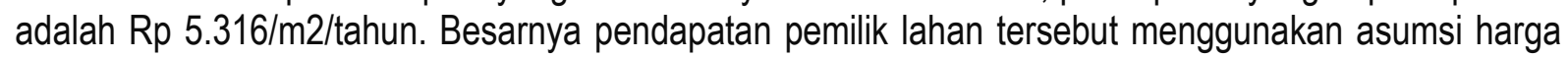
jual gabah kering panen (GKP) sebesar Rp. 500.000/kuintal. Nilai terendah untuk land rent sawah bernilai minus menunjukkan masih terdapat pola pengolahan sawah di Kecamatan Praya yang belum bermanfaat optimal secara ekonomi.

\section{Nilai Lahan Sawah yang Sudah Terkonversi}

a. Sawah Terkonversi Menjadi Rumah

Perubahan sawah untuk dijadikan rumah dan permukiman adalah kejadian terbanyak dalam penelitian ini. Terdapat 216 petak sawah yang terkonversi menjadi rumah dan permukiman di tahun 2010 - 2018. Dengan menggunakan asumsi rumah yang dibangun dapat disewakan dengan pendekatan nilai sewa rata-rata di sekitarnya, diperoleh besar nilai land rent rata-rata untuk rumah dan permukiman sebesar Rp 43.865/m2/tahun. Nilai ini berkisar antara Rp 1.686/m2/tahun hingga Rp 208.333/m2/tahun. Nilai rata-rata land rent rumah dan permukiman lebih tinggi dari nilai rata-rata land 
rent sawah dengan perbandingan $1: 8$ atau 800 kali lebih tinggi dari nilai land rent yang dihasilkan sawah. Terdapat beberapa kelurahan yang memiliki land rent rumah relatif tinggi seperti Kelurahan Renteng, Kelurahan Semayan, Desa Montong Terep dan Kelurahan Praya dan beberapa kelurahan dengan land rent rumah yang lebih rendah seperti Kelurahan Panjisari, Desa Mertak Tombok dan Desa Jago. Besar kecilnya land rent yang dihasilkan dapat menjadi indikasi sebaran kualitas perumahan dan dinamika pasar rumah sewa di Kecamatan Praya.

Tabel 2. Land rent Rumah/Permukiman di Kecamatan Praya (Rupiah/m²/tahun)

\begin{tabular}{clccc}
\hline No. & Desa/ Kelurahan & $\begin{array}{c}\text { Nilai LR } \\
\text { Rata-Rata }\end{array}$ & Nilai Min LR & Nilai Max LR \\
\hline 1 & Aikmual & 21.309 & 1.686 & 64.800 \\
2 & Bunut Baok & 57.377 & 27.624 & 100.000 \\
\cline { 2 - 5 } 3 & Gerunung & 53.513 & 25.000 & 92.308 \\
\cline { 2 - 4 } 4 & Gonjak & 14.585 & 7.895 & 27.778 \\
5 & Jago & 9.374 & 5.143 & 22.222 \\
6 & Leneng & 23.865 & 8.333 & 66.667 \\
7 & Mekar Damai & 13.774 & 10.345 & 17.857 \\
8 & Mertak Tombok & 16.605 & 6.281 & 28.333 \\
9 & Montong Terep & 66.368 & 28.148 & 100.000 \\
10 & Panjisari & 18.598 & 12.195 & 25.000 \\
11 & Prapen & 57.548 & 55.096 & 60.000 \\
\cline { 2 - 4 } 12 & Praya & 63.906 & 21.488 & 208.333 \\
\cline { 2 - 4 } 13 & Renteng & 112.608 & 53.846 & 160.000 \\
\cline { 2 - 4 } 14 & Semayan & 65.519 & 44.118 & 111.111 \\
\cline { 2 - 4 } 15 & Tiwugalih & 39.676 & 20.896 & 98.039 \\
\cline { 2 - 4 } & Total & 43.865 & 1.686 & 208.333 \\
\hline
\end{tabular}

Sumber : Survey data primer peneliti, 2019.

b. Sawah Terkonversi Menjadi Ruko

Penggunaan lahan untuk ruko masih menjadi primadona masyarakat Kecamatan Praya terutama di sepanjang koridor jalan utama di Kelurahan Praya, Kelurahan Renteng, Kelurahan Leneng, Kelurahan Panjasari, Kelurahan Tiwugalih dan Kelurahan Gerunung. Hal ini dapat dilihat dari kecenderungan memusatnya sebaran ruko dalam wilayah tersebut sebagaimana ditunjukkan dalam tabel 1. Nilai land rent ruko di Kecamatan Praya berkisar antara Rp. 23.566/m2/tahun hingga Rp. 2.853.513/m2/tahun dengan rata-rata sebesar Rp 551.707/m2/tahun. Besarnya nilai ekonomi penggunaan lahan untuk ruko ini menjadi daya tarik perubahan orientasi masyarakat untuk mendapatkan nilai tambah yang lebih tinggi. Secara rata-rata, peningkatan nilai yang dapat dinikmati pelaku konversi menjadi ruko adalah 104 kali lipat nilai yang dihasilkan sawah dalam satu tahun per meter persegi. Pemilihan lokasi menjadi hal yang patut diperhatikan karena mengacu pada hasil penelitian, ditemukan kecenderungan land rent ruko tertinggi berada di beberapa kelurahan yang memiliki tingkat aksesibilitas tinggi seperti Kelurahan Renteng dengan rata-rata land rent mencapai 1.252.764/m2/tahun, Kelurahan Tiwugalih dengan nilai rata-rata land rent mencapai Rp. 766.069/m2/tahun dan Kelurahan Praya dengan land rent rata-rata Rp. 696.147/m2/tahun. Nilai tersebut akan berbeda jauh dengan land rent ruko rata-rata di tempat lain seperti di Kelurahan Panjisari dengan land rent sebesar Rp 77.850/m2/tahun atau Kelurahan Gerunung dengan land rent sebesar Rp $57.494 / \mathrm{m} 2 /$ tahun. 


\section{c. Sawah Terkonversi Menjadi Toko Bangunan}

Jenis penggunaan untuk toko bangunan terdapat di 12 petak sawah yang terkonversi sepanjang 2010 - 2018 dengan sebaran di Kelurahan Renteng, Tiwugalih, Montong Terep, Praya, Leneng, Gerunung dan Bunut Baok. Geliat pembangunan wilayah yang dirasakan masyarakat di Kabupaten Lombok Tengah selama 10 tahun terakhir ini tampaknya telah direspon masyarakat dengan inisiasi diversifikasi usaha di luar pertanian salah satunya dengan membuka usaha konstruksi termasuk toko bangunan dan material. Dari hasil penelitian, peluang akumulasi pendapatan dalam usaha ini dapat dilihat dari besarnya nilai land rent untuk jenis penggunaan lahan toko bangunan. Secara rata-rata, nilai land rent dari jenis penggunaan lahan ini adalah Rp 1.096.497/m2/tahun dengan kisaran nilai antara Rp $334.800 / \mathrm{m} 2 /$ tahun hingga Rp 2.641.111/m2/tahun. Nilai ini menunjukkan perubahan lahan sawah menjadi toko bangunan berpotensi meningkatkan nilai ekonomi lahan sebesar 206 kali. Sebaran land rent tertinggi untuk toko bangunan ada di Kelurahan Renteng, Kelurahan Leneng dan Kelurahan Praya.

\section{d. Sawah Terkonversi Menjadi Usaha Batako}

Sejalan dengan nalar berfikir membangun toko bangunan, tampaknya berlangsungnya usaha produksi batako dan paving block serta jenis usaha yang serupa dengan itu di Kecamatan Praya menjadi jenis penggunaan lahan lain yang diusahakan masyarakat untuk meningkatkan kualitas hidup mereka. Sebanyak 12 petak sawah teridentifikasi telah terkonversi untuk dijadikan usaha ini pada tahun 2010-2018. Besarnya rata-rata land rent dengan perubahan lahan ini mencapai Rp 1.096.497/m2/tahun atau 34 kali land rent sawah.

\section{e. Sawah Terkonversi Menjadi Kios/Warung}

Jenis penggunaan lahan berupa kios atau warung menjadi referensi lainnya dalam masyarakat mengkonversi lahan sawahnya di Kecamatan Praya sepanjang tahun 2010 - 2018. Sebanyak 27 petak sawah teridentifikasi berubah fungsi menjadi jenis penggunaan lahan ini dengan sebaran terbanyak ada di Kelurahan Tiwugalih dan Kelurahan Leneng. Secara rata-rata, nilai land rent yang dapat dihasilkan dengan penggunaan lahan kios atau warung sebesar Rp 232.317/m2/tahun. Nilai ini 44 kali lebih tinggi dari nilai land rent sawah. Hal ini menunjukkan potensi keuntungan yang dapat diperoleh masyarakat dengan mengubah fungsi sawah menjadi kios atau warung sebesar 44 kali lipat. Namun, faktor lokasi harus dipertimbangkan. Hal ini terlihat dari perbedaan nilai land rent kios atau warung berdasarkan kelurahan/desa. Land rent tertinggi berada di Desa Aikmual sebagai wilayah yang dilintasi dan berada secara proposional terhadap jalan kolektor primer Praya - Mantang. Nilai land rent kios atau warung di wilayah tersebut dapat mencapai Rp 720.833/m2/tahun, akan berbeda jauh dengan land rent yang dapat dihasilkan di Desa Mertak Tombok yang hanya berpotensi 72.125/m2/tahun.

\section{f. Sawah Terkonversi Menjadi Bentuk Lainnya}

Penelitian ini juga menganalisis nilai land rent untuk jenis penggunaan lain yang berasal dari sawah terkonversi seperti bengkel, apotik, heuler, gudang, klinik, lapangan futsal, usaha rombeng, dan kandang peternakan ayam. Meskipun jumlah petak sawah yang terkonversi untuk jenis penggunaan lahan ini tidak sebanyak jenis penggunaan lahan yang sudah diuraikan sebelumnya, namun nilai land rent yang dihasilkan ternyata masih lebih tinggi juga dari nilai land rent sawah secara umum. Konversi lahan sawah menjadi bengkel ditemukan di 3 petak sawah yang terkonversi masing-masing di Kelurahan Gerunung, Desa Mertak Tombok dan Kelurahan Tiwugalih. Nilai land rent yang dihasilkan sebesar Rp 961.563/m2/tahun dengan nilai yang berkisar antara Rp 317.188/m2/tahun hingga Rp $1.555 .000 / \mathrm{m} 2 /$ tahun. Sawah terkonversi menjadi bangunan apotik dijumpai dalam penelitian ini hanya dalam satu kasus dengan nilai land rent $\mathrm{Rp} 475.250 / \mathrm{m} 2 /$ tahun. Dengan penilaian land rent, diketahui pemanfaatan lahan untuk apotik berpotensi meningkatkan nilai ekonomi lahan sebesar 89 kali dibandingkan sawah.

Konversi sawah menjadi heuluer atau penggilingan padi menjadi pilihan masyarakat terutama yang berada di beberapa kawasan yang masih dominan pertanian. Penggunaan lahan untuk heuleur 
berpotensi meningkatkan nilai ekonomi lahan sebanyak 36 kali lipat dibandingkan nilai ekonomi sawah. Dibandingkan heuleur, nilai ekonomi yang lebih baik dapat dihasilkan dengan pembangunan gudang karena dari analisis land rent diketahui nilai ekonomi lahan sawah meningkat 80 kali lipat jika dijadikan persewaan gudang. Fakta empirik di lapangan menunjukkan sebaran pembangunan gudang baru sebagai wujud konversi sawah berada di sekitar Kelurahan Leneng, Kelurahan Panjisari dan Kelurahan Renteng.

Pembangunan klinik kesehatan juga terpaksa mengorbankan sawah di Kecamatan Praya. Namun, pembangunan klinik kesehatan tersebut akan meningkatkan nilai lahan sawah tersebut menjadi lebih tinggi lagi yaitu $\mathrm{Rp} 1.096 .250 / \mathrm{m} 2 /$ tahun atau 206 kali lipat. Demikian pula dengan usaha lapangan futsal yang sepanjang tahun 2010-2018 telah merubah beberapa petak lahan sawah di Kecamatan Leneng justru berhasil meningkatkan nilai lahan menjadi Rp 72.371/m2/tahun. Penggunaan lahan untuk futsal merubah rasio nilai lahan sawah menjadi $1: 14$. Jenis usaha lainnya yang dijadikan masyarakat sebagai referensi perubahan lahan sawah adalah usaha rombeng dan kandang peternakan ayam. Untuk kedua jenis penggunaan lahan ini nilai land rent yang dihasilkan sebesar Rp 36.486/m2/tahun untuk usaha rombeng dan Rp 47.000/m2/tahun untuk kandang peternakan ayam. Meskipun masih berada pada kelompok cluster pertanian, usaha peternakan ayam ini dirasa jauh lebih menguntungkan dibandingkan lahan sawah.

\section{Sebaran Spasial Nilai Lahan Sawah yang Belum dan Sudah Terkonversi}

Secara keseluruhan, rata-rata nilai lahan non sawah adalah Rp 174.315/m2/tahun atau 32,7 kali lipat dibandingkan rata-rata nilai lahan sawah yang hanya $\mathrm{Rp} \mathrm{5.317/m2/tahun.} \mathrm{Ini} \mathrm{artinya,} \mathrm{potensi} \mathrm{nilai}$ lahan secara ekonomis akan semakin meningkat hingga mencapai 32,8 kali lipat dari kondisi sawah menjadi non sawah. Besarnya potensi tersebut patut diduga menjadi faktor pendorong masifnya konversi lahan sawah di Kecamatan Praya. Secara teoritik, besarnya potensi land rent yang kemudian disebut dengan nilai opportunity cost dapat memberi penjelasan rasional dan ilmiah mengapa petani tidak mempertahankan lahan sawahnya untuk pertanian.

Rasio antara nilai lahan sawah terkonversi dan yang tidak terkonversi ini akan semakin beragam jika diamati per wilayah administrasi desa atau kelurahan. Rasio terbesar terdapat di Kelurahan Renteng dengan perbandingan 1:170,8 dan rasio terendah ada di Desa Mekar Damai dengan perbandingan 1:2,7. Perbedaan nilai rasio ini menunjukkan adanya perbedaan karakteristik wilayah secara ekonomi lahan.

Tabel 3. Rasio Nilai Lahan Sawah Tidak Terkonversi Terhadap Sawah Terkonversi di Kecamatan Praya

\begin{tabular}{clccc}
\hline No. & Desa/ Kelurahan & $\begin{array}{c}\text { Nilai Lahan } \\
\text { Sawah Tidak } \\
\text { Terkonversi }\end{array}$ & $\begin{array}{c}\text { Nilai Lahan Sawah } \\
\text { Terkonversi }\end{array}$ & Rasio \\
\hline 1 & Aikmual & 5.561 & 136,396 & $1: 24,5$ \\
2 & Bunut Baok & 5.032 & 100.280 & $1: 19,9$ \\
3 & Gerunung & 5.322 & 117.576 & $1: 22,1$ \\
4 & Gonjak & 6.171 & 45.845 & $1: 7,4$ \\
5 & Jago & 5.036 & 39.471 & $1: 7,8$ \\
6 & Leneng & 5.213 & 168.384 & $1: 32,3$ \\
7 & Mekar Damai & 4.969 & 13.774 & $1: 2,7$ \\
8 & Mertak Tombok & 5.242 & 184.530 & $1: 35,2$ \\
\hline 9 & Montong Terep & 4.746 & 223.377 & $1: 47,1$ \\
\cline { 3 - 5 } 10 & Panjisari & 7.298 & 112.406 & $1: 15,4$ \\
\cline { 2 - 4 } 11 & Prapen & 7.466 & 57.548 & $1: 7,71$ \\
\cline { 2 - 4 } 12 & Praya & 6.700 & 196.534 & $1: 29,3$ \\
\hline
\end{tabular}




\begin{tabular}{rrrrr}
\hline 13 & Renteng & 4.162 & 710.909 & $1: 170,8$ \\
\cline { 3 - 4 } 14 & Semayan & 4.869 & 94.543 & $1: 19,4$ \\
15 & Tiwugalih & 3.939 & 182.922 & $1: 46,4$ \\
\cline { 3 - 4 } & Total & 5.317 & 174.315 & $1: 32,7$ \\
\hline
\end{tabular}

Sumber : Analisis Peneliti, 2019.

Nilai lahan sawah yang belum terkonversi di Kecamatan Praya jika dispasialkan dari titik sebaran kuesioner dengan metode poligon thiessen, menunjukkan sebaran nilai lahan yang relatif lebih tinggi tersebar bagian selatan sekitar Bendungan Batujai, sekitar Lendang Beso dan Tiwubokah Kelurahan Praya, di sekitar Bogak Kelurahan Tiwugalih Galih, Kelurahan Gonjak, Dusun Paoktawah di Desa Bunutbaok, Dusun Kuangrundung di Kelurahan Renteng, Desa Aikmual dan Desa Mekardamai serta Desa Mertak Tombok dan Desa Jago. Tingginya nilai lahan di kawasan tersebut dapat dijadikan acuan nilai potensi yang dapat digali untuk pengembangan sektor pertanian di Kecamatan Praya mengingat penelitian ini menggunakan sampel petak sawah yang ada di sepanjang koridor jalan di Kecamatan Praya. Simbol poligon yang diberi warna lebih gelap dalam Gambar 3.A menunjukkan sebaran kawasan yang dimaksud dengan nilai land rent sawah lebih dari Rp.7.947/m2/tahun.

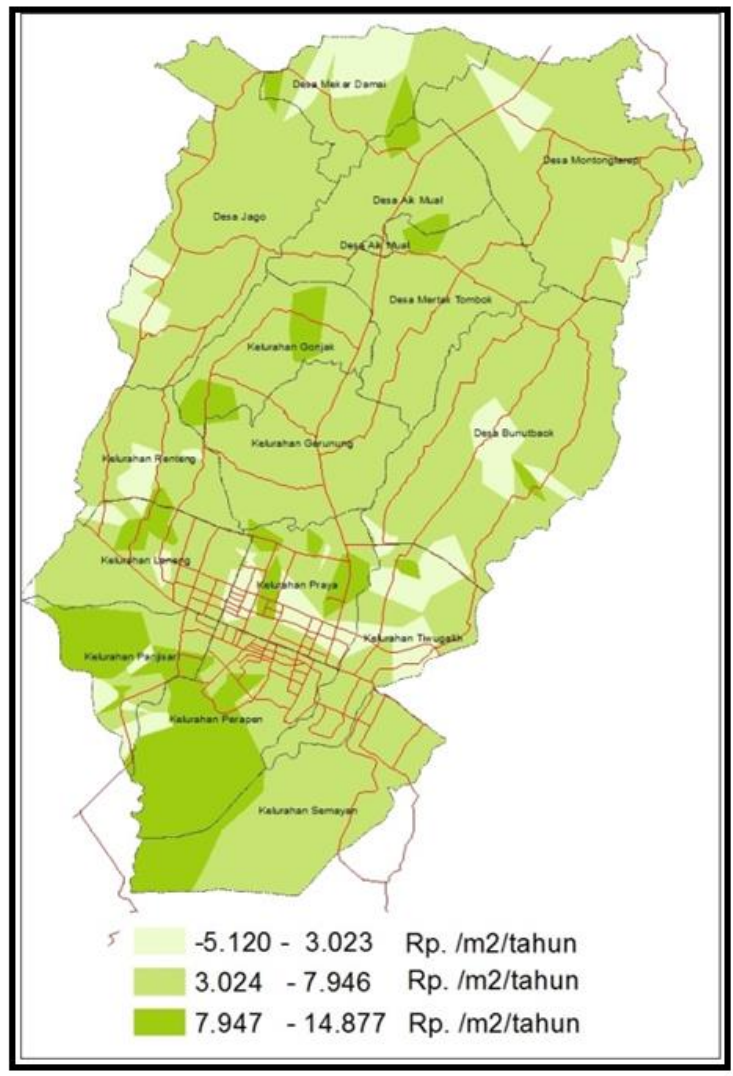

A

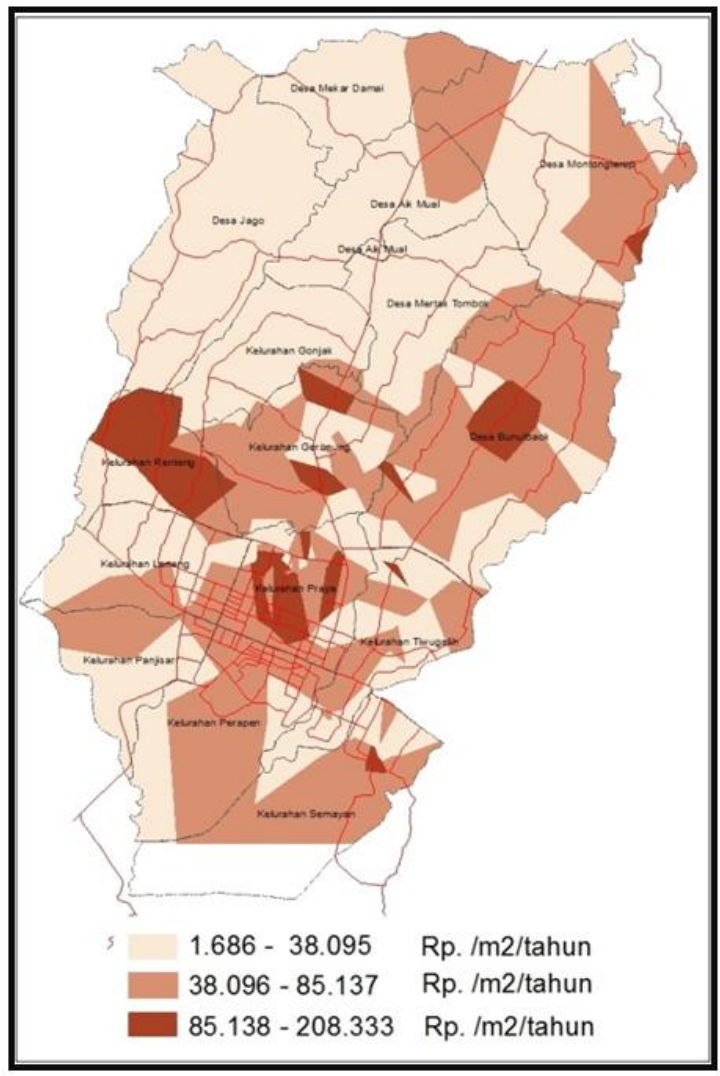

B

Gambar 3. Peta Sebaran Land Rent Sawah Tidak Terkonversi (A) dan Peta Sebaran Land Rent Sawah Terkonversi (B)

(Sumber: Peneliti, 2019)

Pola spasial persebaran nilai lahan sawah yang terkonversi di Kecamatan Praya dapat diamati pada Gambar 3.B dengan warna paling gelap menunjukkan nilai yang paling tinggi. Jika dispasialkan dari titik sebaran kuesioner sawah yang sudah terkonversi dengan metode poligon thiessen, didapatkan 
beberapa kawasan yang memiliki nilai lahan yang relatif lebih tinggi dengan persebaran sekitar Tengari Kelurahan Praya, sekitar Kelurahan Renteng, sekitar Desa Montong Terep, sekitar Desa Bunutbaok, dan sekitar Kelurahan Gerunung. Nilai land rent di kawasan-kawasan tersebut meningkat setelah mengalami konversi sawah sehingga nilai opportunity cost bagi petani dan pemilik lahan di kawasan tersebut akan lebih tinggi dibandingkan kawasan lain dengan kisaran mulai dari Rp 85.138/m2/tahun.

\section{SIMPULAN}

Berdasarkan hasil analisis data serta pembahasan pada penelitian ini, maka dapat disimpulkan sebagai berikut. Perbandingan nilai ekonomi lahan untuk kajian konversi sawah dapat ditunjukkan oleh besar rasio rata-rata nilai land rent sawah terhadap land rent hasil konversi yang menunjukkan potensi peningkatan land rent akibat konversi lahan sawah menjadi penggunaan lahan non sawah. Secara keseluruhan, nilai rasio yang dihasilkan adalah $1: 32,7$. Artinya, potensi nilai lahan secara ekonomis akan meningkat 32,7 kali lipat dengan perubahan sawah menjadi lahan untuk peruntukan lainnya. Kajian nilai lahan ini dapat memberikan penjelasan yang rasional dalam memahami konversi lahan sawah di wilayah penelitian yang menunjukkan besarnya opportunity cost jenis penggunaan non sawah yang dapat diraih oleh petani pemilik lahan di Kecamatan Praya dengan mengkonversi lahan sawah mereka.

\section{DAFTAR PUSTAKA}

Agrawal, S. \& Gupta, R.D. (2016). School Mapping and Geospatial Analysis of Schools in Jasra Development Block of India. ISPRS-International Archives of the Photogrammetry, Remote Sensing and Spatial Information Sciences, Volume 41 (B2): 145-150.

Akib, N.N. (2002). Studi Keterkaitan antara Nilai Manfaat Lahan (Land Rent) dan Konversi Lahan Pertanian di Kecamatan Pancoran Mas Kota Depok. Tesis. Bogor: Institut Pertanian Bogor.

BPS (2019). Lombok Tengah dalam Angka 2019. Praya: Badan Pusat Statistik.

Hamdan. (2012). Ekonomi Konversi Lahan Sawah Menjadi Kebun Kelapa Sawit di Kecamatan Seluma Selatan Kabupaten Seluma Provinsi Bengkulu. Tesis. Bogor: IPB.

Harini, R., Yunus, H.Si., Kasto., Hartono, S. (2012). Agricultural Land Conversion: Determinants and Impact for Food Sufficiency in Sleman Regency. Indonesian Journal of Geography. 44 (2): $120-$ 133.

Jauhiainen., Jussi, S. (2006). Urbanisation, Capital and Land-Use in Cities. Dalam Place and Location Studies in Environmental Aesthetics and Semiotics V. Diakses pada 14 April 2019 dari http://www.eki.ee/km/place/koht_5.htm.

Krannich, J.M. (2006). A Modern Disaster : Agricultural Land, Urban Growth and The Need for Federally Organized Comprehensive Land Use Planning Model. Cornell Journal of Law and Public Policy: 16 (1), Article 2: 57-99.

Nguyen, T.H.T., Tran, V.T., Bui, Q.T., Man, Q.H., Walter, T.d.V. (2016). Socio-Economic Effects Of Agricultural Land Conversion For Urban Development: Case Study of Hanoi, Vietnam. Land Use Policy. 54: 583-592.

Pambudi, Andika (2008). Analisis Nilai Ekonomi Lahan (Land Rent) pada Lahan Pertanian dan Permukiman di Kecamatan Ciampea Kabupaten Bogor. Skripsi. Bogor: Fakultas Pertanian IPB.

Rondhi, M., Pratiwi, P.A., Handini, V.T., Sunartomo, A.F., Budiman, S.A. (2018). Agricultural Land Conversion, Land Economic Value, and Sustainable Agriculture: A Case Study in East Java. Land. 7. 148: 1-19. 
Rustiadi, E., Saefulhakim, S., \& Panuju, D.R. (2009). Perencanaan dan Pengembangan Wilayah. Jakarta: Crespent Press \& Yayasan Obor Indonesia.

Solecka, I., Sylla, M., \& Swiader, M. (2017). Urban Srawl Impact on Farmland Conversion in Suburban Area of Wroclaw Poland. IOP Conference Series: Materials Science and Engineering. 245 (2017) 072002

Suparmoko. (1997). Ekonomi Sumberdaya Alam dan Lingkungan. Yogyakarta: Pusat Studi Ekonomi UGM. 